\title{
Angklung in the Era of Industry 4.0
}

\section{Priyo Dwi Wibowo ${ }^{1, *}$ Feri Budi Setyawan ${ }^{2}$ Kun Setyaning Astuti ${ }^{1}$}

\author{
${ }^{1}$ Department of Art Education, Graduate School, Yogyakarta State University, Yogyakarta, Indonesia \\ ${ }^{2}$ Department of Elementary School Teacher Education, Ahmad Dahlan University, Yogyakarta, Indonesia \\ * Corresponding author. Email: priyo21dwi@gmail.com
}

\begin{abstract}
Angklung is a Sundanese musical instrument made of bamboo. We have to shake it to get the tune. Angklung has been through a long period of times in history before it becomes a masterpiece of one of Sundanese artistry. It has been through many changes, beginning from its form, functions and tune itself. Angklung experienced its downturn at the beginning of the 20th century. But it survived. Angklung can suit itself to this changing modern world by adjusting its musical scale from pentatonic to diatonic. UNESCO has granted Angklung the Representative List of Intangible Heritage of Humanity on January 16, 2011.
\end{abstract}

Keywords: angklung, art, tradition.

\section{INTRODUCTION}

Art and humans are almost inseparable. Most aspects in the life of humans are always influenced by art. Any phenomenon or event around people's life can be transformed into art.

Art is a terminology that represents any activity related to humans' creativity in expressing their taste and emotions to produce a beautiful work of art. In general, it is the most common and recognized expression of human creativity, and is considered to be the human superiority. A work of art is a creative work in which what is created is not just an object, but a critical result of everything that exists [3]. In the context of culture, art is an important and inseparable part of human culture. Art as an element of culture is vital because it reflects creativities developed from the culture itself. It creates and gives opportunities to move, maintain, transmit, develop and then re-create new cultures [5]. Art is one of the necessities of human life to feel a particular sense of beauty. Traditional arts in West Java are on the verge of extinction, evidenced by the loss of 55 types of traditional arts in in the region, with 77 others nearly extinct. They are already included in the museum's collection as it has been difficult to identify and describe them while the artists have been gone. Only 78 types of traditional arts can develop, based on the results of research by Atiek Supandi and several stakeholders regarding the existence of traditional arts in West Java.

Meanwhile, the Director-General of Cultural Values, Arts, and Films of the Indonesia's Ministry of Culture and Tourism, Ukus Kusawara in a dialogue of culture in Kuningan Regency in September 2011, said that at present there are only 150 traditional arts, most of which are endangered. It is unfortunate little has been done so far to solve this problem. One such traditional art is Angklung, an Indonesian traditional musical instrument made from bamboo [2].

\section{METHOD}

\section{$2.1 \quad$ Method}

This was a descriptive qualitative study [6] where every social phenomenon found in the field was described and analyzed in comparison with existing theories. Qualitative data were collected using interview and observation techniques. Interviews were conducted with community leaders, cultural figures, artists, and other selected informants who knew and understood Angklung deeply.

\subsection{Data}

Observations were carried out to obtain data that cannot be revealed through interviews. In addition to these two data collection techniques, a literature study was also conducted to obtain data from written sources (secondary data). The selection and determination of informants were carried out in stages using snowballing technique, with the first objective of getting a key informant. The researchers then asked the first informant to look for the next informant, and so on until a number of informants were obtained and felt sufficient to capture all the data needed for this study.

\section{RESULTS AND DISCUSSION}

\subsection{Result}

Angklung is a Sundanese musical instrument made from bamboo [8]. Emil Salim (Former Minister of Environment of the Republic of Indonesia in the Soeharto era) thought that the Sundanese were so familiar with bamboo trees that the concept of bamboo culture eventually emerged. He said that if one intends to destroy the Sundanese, he or she must first 
destroy the bamboo trees (quoted from the Sunda Mangle Magazine).

An article entitled "Awi" (Sundanese: bamboo) defines "Awi" as "ajining wiwitan ingsun medal" (self-knowledge born into the world), or "ajining wiwitan ingsun dahar" (knowledge of life) [9]. In short, it means that in life there are both "hakikat" (essence) and "sareat" (law). The article tells a simple experience of living in a rural area, illustrating the close relationship between Sundanese people and bamboo [9]. Sundanese is a group of people who cannot distance themselves from the natural environment, especially from plants [9].

Angklung has gone through a very long history before it finally managed to exist as a noble art.

\subsection{Discussion}

According to some sources, Angklung is a musical instrument made from bamboo originating from the Island of Java, specifically the Sundanese land [8]. It is said that Angklung has existed since the days of the Sundanese Kingdom. Some accounts from European travelers in the 19th century indicate that local people often played Angklung in this area. Although Angklung is also wellknown in other regions of Java, this instrument is more popular in the Sundanese land.

One reference, the Samanyata Bulletin Edition II/2009, published by the Ministry of Culture and Tourism, informs that Dr. Groeman stated that Angklung had become a favorite art performance throughout the archipelago even before the Hindu era [2].

In West Java, Angklung has been played since the 7th century by Baduy people from Kanekes Village. Among Sundanese people, the existence of Angklung is closely related to the myth of Nyai Sri Pohaci or Dewi Sri as a symbol of the rice goddess. In subsequent developments, Angklung is also accompanied by rhythmic movements and "ibing" (dance) elements with certain patterns and rules [10]. Some types of traditional Angklung which still exist today in the Sundanese community in West Java and Banten, include:

1) Angklung Kanekes

2) Angklung Dogdog Lojor

3) Angklung Gubrag

4) Angklung Badeng

5) Angklung Buncis

In the old Sundanese community, Angklung has been known as a traditional musical instrument that does not merely function as a medium of entertainment, but also has an important function in traditional rituals around agriculture. The development of education has further brought enormous changes to the development of this art.

Daeng Soetigna is a great maestro and artist who has been able to change the Angklung scales from pentatonic in the traditional Angklung (da, mi, na, ti, la) to chromatic-diatonic in the modern one (do, di, re, ri, mi, fa, fi, sol, sel, la, li, ti, do) [7].

Angklung was created by the Sundanese tradition as a tribute to Dewi Sri, who was seen as a goddess of rice. At the beginning of the 20th century, the traditional Angklung had once disappeared, particularly due to a ban from the Dutch East Indies Government. The revival of Angklung began with an innovation created by Daeng Soetigna in 1938, who succeeded in changing the Angklung scale from pentatonic to chromatic-diatonic scale.

During the Japanese occupation in 1944, Mr. Daeng formed an Angklung group whose members were 5 and 6 graders of Kuningan Elementary School. After the proclamation of the Independence in 1945, a public junior high school was established, whose students were the former students of Kuningan Elementary School in addition to those from other regions. In 1946, he then created another Angklung group. One of the highlights of his Angklung show was during the Linggajati Agreement in November 1946. Around 1947, his Angklung performance was recorded on vinyl by special technicians from the Netherlands. In 1955, during the Asia Africa Conference at Merdeka Building, Bandung, Daeng Sutigna was also asked to hold an Angklung concert he had created.

Since then, his diatonic Angklung has often been shown at official events, such as at the World Fair in New York, the United States (1964), where he led art shows including Angklung at the Indonesian pavilion for 8 months. In 1967, he held a "muhibah" tour around various cities in Malaysia. For his services in developing Angklung, Daeng Sutigna received an award from the Governor of West Java (1966), an award from the Governor of Jakarta (1968), Satya Lencana Budaya (Cultural Service Medal) from President Soeharto (1968), Anugerah Bintang Budaya Parama Dharma (Cultural Merit Star) from President Susilo Bambang Yudhoyono (2007), and is being proposed to get the title of national hero from West Java in art and culture. Daeng Sutigna died in Bandung on April 8, 1984 and was buried in the Heroes Cemetery in Cikutra, Bandung.

\section{CONCLUSION}

Angklung has now begun to be widely known in the world as one type of art originating from Indonesia. At the beginning of its appearance, Angklung emerged as a traditional art of an agrarian society. The resulting sound tones are pentatonic (da, $\mathrm{mi}$, na, ti, la). Early in the 20th century the existence of Angklung had experienced a downturn. At that time, Angklung was only played by buskers to earn a fortune from house to house.

The political situation during the Dutch colonial era had caused Angklung's artistry to plummet again. At that time, the colonial government considered Angklung dangerous because it could ignite the fighting spirit of the Indonesian nationalists. Through the Angklung he created, Mr. Daeng was able to elevate Angklung into a noble art. The peak of the success in promoting Angklung was obtained when UNESCO declared Angklung as the Representative List of the Intangible Cultural Heritage of Humanity, which was declared on January 16, 2011.

\section{REFERENCES}

[1] Hastanto, Sri, "Musik Angklung sebagai Alternatif Sarana Pengembangan Musikalitas, Moral dan Identitas [Angklung Music as an Alternative Means of Developing Musicality, Morals and Identity]”. Makalah tidak diterbitkan (2002) 
[2] Kurnia, Ganjar. Deskripsi Kesenian Jawa Barat [The Description of West Java Art.]. Kerjasama Dinas Kebudayaan \& Pariwisata, Jawa Barat [dengan] Pusat Dinamika Pembangunan, Unpad, 2003.

[3] Greg Soetomo, S. J. Krisis Seni Krisis Kesadaran. [The Crisis of Art Crisis of Awareness]. Kanisius, 2003.

[4] Sumarno, Tatang. Pirous, Erna Garnasih, "Membela Kehormatan Angklung. Sebuah Biografi dan Bunga Rampai Daeng Soetigna [Defending the Angklung Honor. A Biography and Flower of Daeng Soetigna]", Bandung: Yayasan Serambi Pirous, (2007).

[5] Sutaarga, M. Amir, "Tjiri-tjiri Antropologi Fisik dari Penduduk Pribumi” dalam buku: Penduduk Irian Barat (editor Koentjaraningrat dan Harsja W. Bachtiar) [the physical anthropological features of the indigenous population in the book: Residents of West Irian (editors of Koentjaraningrat and Harsja W. Bachtiar], hal. 22-23 (1963).

[6] Sugiyono. Metode penelitian pendidikan :(pendekatan kuantitatif, kualitatif dan R \& D) [Educational research methods: (quantitative, qualitative and R\&D approaches]. Alfabeta, 2015.
[7] Wiramiharja, Obby A.R, “Angklung Pa Daeng [Angklung Pa Daeng]”. Makalah disampaikan pada Seminar Nasional Angklung di ITB, (1989).

[8] Traverse, Indonesia. "Indonesia Traverse." Traverseid, 26 Feb. 2018, http://raverse.id/budaya/angklung-keindahan-harmoninada-bambu-dari-tatar-sunda/@himsaifanah.

[9] Rusnandar, Nandang. "AWI.” AWI, 16 Nov. 2009 , https://sundasamanggaran.blogspot.com/2009/11/awi.html

[10] Wiramihardja, Obby. "Sekilas Sejarah Angklung di Indonesia." Kemendikbud, 24 November 2019, http://kebudayaan.kemendikbud.go.id/ditwdb/angklung/= update 